\title{
Economic Lessons Insert the Islamic Economy: How the Interest Action in Science High School Student Majoring?
}

\author{
Luqman Hakim, Moch. Khoirul Anwar ,Riza Yonisa Kurniawan , Triesninda Pahlevi
}

\begin{tabular}{l} 
ARTICLE INFO \\
\hline Article History: \\
Received 05.09.2018. \\
Received in revised form \\
19.12.2018 \\
Accepted \\
Available online 01.04.2019.
\end{tabular}

\section{INTRODUCTION}

\begin{abstract}
Development Islamic economy in Indonesia is currently very rapid. Based on data from Bank of Indonesia in 2012, The islamic banking market share of the national banking sector increased by $0,6 \%$. That it requires human resources who are capable for managing it. However, at this time has not fully insert Islamic economy in economic learning in senior high school and process of economic learning need insert islamics economy in teaching material. This study describes student interest in Islamic economics insert s economic subjects throughout East Java. The research method used was a survey using interest questionnaires to students and interviews with teachers. Samples were taken using purposive sampling technique, namely schools that have an science majoring in economic interest. Sample consisted of 20 student randomly selected in Surabaya 10 Public High School at East Java. The results showed that $55 \%$ of students were very interested and $45 \%$ of students were of moderate interest to learn more about these subjects. This shows that the response of students is very good if these economic subjects are included in Islamic economics. Whereas from the results of interviews with teachers it was concluded that Islamic economic inserts should not be included in local content but included in the national curriculum on economic. In the future there will be a source of economic teaching materials insert Islamic economy, that will produce experienced human resources in Islamic economy.
\end{abstract}

(C) IJERE. All rights resenved

Keywords:

High School, Student, Islamic economic insert

The development of the Islamic economy in Indonesia is very rapid, given that Indonesia is the largest country adhering to Islam. Based on data from the Indonesian Central Bureau of Statistics (BPS) in 2010, 87\% of Indonesia's population adhered to Islam. As the largest Muslim community in the world, Indonesia is optimistic in implementing the Islamic Economy as a system (Rahajeng, 2013). This is evidenced by the establishment of Islamic-based businesses. The establishment of Bank Muamalat in 1992 was one of the emergence of Islamic economics in Indonesia (Niswatin, Hasiru, \& Rasuli, 2017).

One of the factors that many companies own is issuing Islamic-based products because Islamic products are in great demand by the Indonesian population. Research by Adespa (2017) showsthat the factors that influence people's interest in saving in Islamic banks are (1) the marketing mix factor; (2) cultural factors; (3) social factors; (4) personal factors; and (5) psychological factors. The increasing interest of the community to switch

\footnotetext{
${ }^{1}$ Corresponding e-mail: rizakurniawan@unesa.ac.id ,orcid.org/0000-0003-2419-210X; 2 orcid.org/0000-0003-3681-4762; 3; orcid.org/0000-0003-2419-210X 4; orcid.org/0000-0003-1717-9409

Universitas Negeri Surabaya ${ }^{1,2,3,4}$
} 
to choosing Islamic products, the opportunities for job vacancies are increasingly wide open, especially in the field of Islamic economics. This opportunity must be balanced with Human Resources (HR) with a background in Islamic economics.

According to the teacher, there are usually problems with students but they are not suitable for students according to the interests and talents of students. The most important problem at the club is the activity of insufficient time, unable to carry out club activities and lack of material variations and activities. For these reasons, the teacher is offered new and more appropriate materials and enriches the club's activities. After all the suggestions, the teacher asks students to channel themselves to club activities according to their interests and talents (Karaağaç, 2017).

The results of the study (BAYRAKTAR, 2018) state that field selection is directly influenced by students' future goals, their courses are successful, family expectations and their interests and skills. It was observed that gender and age variables of students did not make a significant difference in results. In addition, it has been determined that the economic level of the student's family and the preferences of closest friends do not have the expected effect in field selection, but rather that individual expectations have a guiding function.

The fact is that the development of an Islamic-based business is not balanced with human resources with a background in Islamic economics. About $10 \%$ have an Islamic economics background and 90\% do not have an Islamic economic background (Sari, 2014). At present, there is still a wide disparity in human resource capacity in the Islamic business and business industry, as well as Islamic banking compared to conventional business and banking. The nontion of islamic banking mortgage product, especially islamic financing mortgage, from the internal party has not weel distributed yet (Heykal, 2014). This condition is an obstacle to carrying out its business activities.

Table 1. Background of Islamic Bank Employee Education

\begin{tabular}{|l|l|l|}
\hline \multicolumn{1}{|c|}{ Level of education } & $\begin{array}{c}\mathbf{2 0 1 1} \\
\mathbf{( \% )}\end{array}$ & $\begin{array}{l}\mathbf{2 0 1 2} \\
\mathbf{( \% )}\end{array}$ \\
\hline High School & 5,3 & 6,2 \\
Diploma & 12,1 & 18,7 \\
Bachelor of Economic & 39,1 & 38,0 \\
Bachelor of Law & 7,2 & 6,2 \\
Bachelor of social science and political & 6,8 & 5,2 \\
science & & \\
Bachelor of Agriculture & 6,3 & 4,9 \\
Bachelor of Engineering & 9,2 & 7,6 \\
Bachelor of Islamic Economics & 8,6 & 9,1 \\
Master & 5,3 & 4,1 \\
\hline
\end{tabular}

Source: Bank Indonesia Islamic Banking Statistics Data, 2013 
In order to realize an Islamic-based economy, it must be balanced with the level of public understanding of Islamic economics (Niswatin et al., 2017). Educational institutions as providers of information from the community have a very strategic role. At present, the introduction of Islamic-based science is still in the scope of Higher Education while at the high school level it is still very minimal (Hakim, Anwar, Kurniawan, \& Pahlevi, 2017).

As a basis for Islamic values, the role of primary and secondary education is very necessary. Of course by revamping the national curriculum or adding Islamic values to one of the subjects. Based on the results of interviews with economic subject teachers in one of the East Java high schools that the teacher still teaches conventional economic material, while for Islamic economics it has never been taught. So far learning at the primary and secondary level has been emphasized more on conventional economic material so that humans unwittingly form economic beings (homo economicus / economic man) and abandon religious values as a foundation in behaving including in economic behavior (Mintaroem, 2009). Ibnu Khaldun divides knowledge into two major parts, one of which is the naqliyah science (textual). This model of science seeks to explain the faith, regulate religious obligations and enforce shari'ah laws. In other words, the science of naqliyah is the science of religion with all kinds and the supporting sciences that are related and prepared to be studied (Syafi'i, 2015). Thus the concept of Islamic economics reveals how moral values are combined with broader economic transformation projects (Rudnyckyj, 2009). The values contained in Islamic economics will have an impact on people's behavior which is not only seen in terms of religious values.

One effort that can be done by educational institutions is through curriculum reconstruction and the addition of Islamic economics to economic subjects, so that early on students get a debriefing on Islamic economics so that the realization and development of Islamic economics can be achieved. The reconstruction of the curriculum aims to get students to get an understanding and awareness of their role later as business people in the future (Mintaroem, 2009).

From the above conditions, in this study will be discussed about student interest and teacher perceptions of economic economics insert Islamic subjects in high school (SMA). Interest can be interpreted as the influence of oneself on activities that provide the desired attraction at that time (Deci, 1992).

\section{METHOD}

The type of research used in this study is descriptive research. The research method used is the survey method by using interest questionnaires to students and interviews with teachers.

The population of this study was all high school students in Indonesia. The sample was taken using a purposive sampling technique that is a school that has anc science majoring in economic interest. The research subjects were students of the Science Department in the field of economic specialization in Surabaya 10 Public High School with a sample of 20 students. Study sample in school to test the results of developing Student Worksheets insert Islamic economy in students can improve Islamic economy interest. 
Student interest questionnaires are developed from theories of interest which have indicators including (1) attention; (2) interest; (3) feeling sad; and (4) student involvement. While the results of interviews with teachers are used to determine the perceptions or opinions of teachers on economic subjects inscribed with Islamic economics.

The study design, include activities preparation learning materials conducted by researchers. Implementation research is the implementation phase of the learning materials has been prepared. Along with the implementation of learning, observers observe the activities undertaken Lecturers and Students. In carrying out the implementation of learning, researchers have prepared guidelines for observation instruments and provided for the observer.

Reflection is the final stage of each cycle. At this stage, researchers and observers gathered to discuss the data obtained in the study that has been done. If in the implementation of learning acquired data or records are deficient in the learning process so that phase should be done by researcher re planning to produce a new plan and are ready to be implemented in the next cycle.

\section{RESULTS AND DISCUSSION}

The results of research on student interest in Islamic economics insert economic subjects.

Table 1. Distribution of Frequency of Student Learning Interests

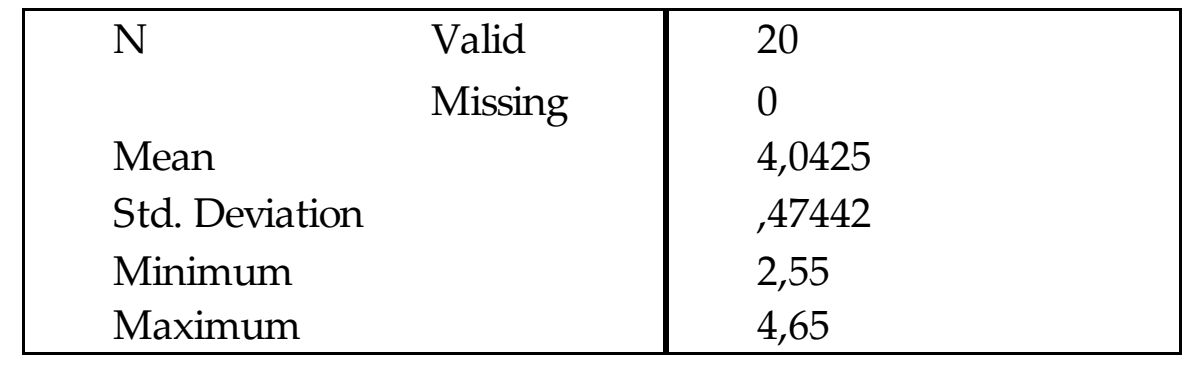

Source: data processed

The survey was conducted on 20 respondents $(\mathrm{N}=20)$. Based on the frequency distribution table above, we can know that the average respondent has a high interest with an average interest of 4.0425 . Whereas the standard deviation is 0.47442 . Minimum value of 2 and maximum value of 4 . 


\section{Student Learning Interest}

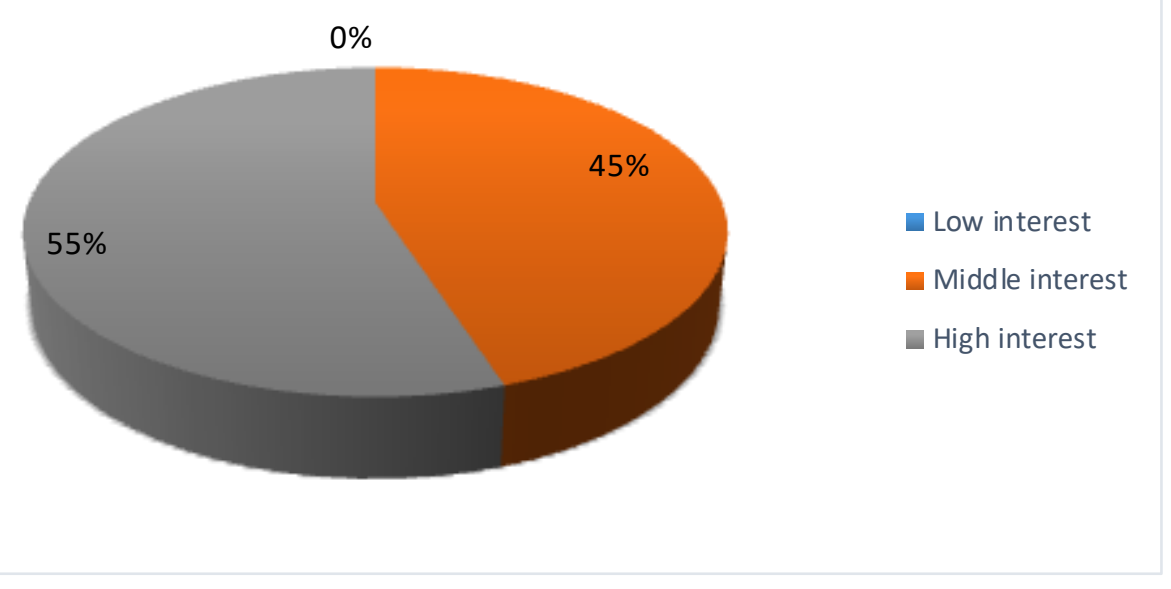

Figure 1. Interest in Student Learning

Based on Figure 1 above, it can be concluded that learning interest is categorized as very high at $55 \%$ while the moderate category is $45 \%$ and the rest in the low category is $0 \%$ Student interest in studying Islamic economics. Indicator of the student learning is the responsibility of students in participating in economic learning; students respond to economic learning; collaboration between students in learning; and the level of student satisfaction after following Islamic economics learning.

\section{Student Interest In Islamic Economic Inserts}

Before measuring student interest in Islamic economics insert economic subjects. It is necessary to conduct a trial in the field of application of Islamic economics insert subjects in the Science Department of economic specialization. Implementation is carried out by testing teaching materials in the form of student worksheets in economic subjects that have been incorporated into Islamic economics. The student worksheets is structured on the basis of developing a syllabus for economic subjects inscribed with Islamic economics. While the implementation of learning activities refers to the Learning Implementation Plan (RPP) which has been developed based on the 2016 revised curriculum.

From the results of trials in the field, then measured student interest in economic subjects that have been incorporated in Islamic economics. Interest is an important and unique motivational variable and psychological state when there is an interaction between people and objects of interest (Hidi, 2006; Swarat, Ortony, \& Revelle, 2012). Interest changes have a strong and broad influence on students (Palmer, 2009).

Students' interest in Islamic economic inserts on economic subjects is very good. The results of the questionnaires that have been distributed to students show that $55 \%$ stated that they were very interested and $45 \%$ expressed very much interest (figure 1). During the trial, attention, cognitive thinking and student interest increased, according to the opinions of Hidi (2006) and Pintrich \& Schunk (1996) that interest arises when there is an increase in attention, interest, concentration, cognitive thinking, influence, feeling happy and student involvement. Students are interested in learning more about economic subjects inscribed with Islamic economics. They werw very enthusiastic when conducting trials with teaching materials using student worksheet. 
The results of previous studies by (Niswatin et al., 2017) show that students are interested in learning more about Islamic economics. Students implement Islamic values that have a positive impact on their behavior. (Mintaroem, 2009). The value contained in Islamic economics is not only about ontology, axiology, epistemology, and the methodology, but it is widely applied in daily life activities of the community (Yusdani, 2007). These values include monotheism (faith), 'adl (justice), nubuwwah (prophethood), Khilafah (government), and ma'ad (results) (Adinugraha, 2013).

\section{CONCLUSION}

The results of the field trials show that students' interest in learning more by $55 \%$ of students is very interested and $45 \%$ of students are interested. Furthermore, this study emphasizes the teacher's perception of the implementation of economic subjects that are embedded in the Islamic economy. The teacher agrees more if the Islamic economy is included in the national curriculum to better shape the personality and character of the Indonesian nation. The hope is that students can implement the values contained in Islamic economics and will impact on the creation of human resources in the field of Islamic economics to meet the needs of the labor market

This research is only limited to the insertion of Islamic economics on economic subjects. The next research is expected to be more on the development of a national curriculum which added Islamic economics from elementary school to high school and Islamic principles can also be expanded in various fields not limited to economic learning. The hope is that the character and personality of the Indonesian people are better.

\section{REFERENCES}

Adespa, R. (2017).Factors that influence customer interest in saving in Islamic banks. $A l$ Masraf: Jurnal Lembaga Keuangan Dan Perbankan, 2(1), 43-57.

Adinugraha, H. H. (2013). Norms and values in Islamic economics. Media Ekonomi $\mathcal{E}$ Teknologi Informasi, 21(1), 49-59.

Bayraktar, Y. (2018). Investigation of factors affecting field selection of 11th grade in high school students. International Journal of Educational Research Review, 3(3), 23-31.

Deci, E. L. (1992). The relation of interest to the motivation of behavior: A self-determination theory perspective. NJ: Lawrence Erlbaum Associates.

Hakim, L., Anwar, M. K., Kurniawan, R. Y., \& Pahlevi, T. (2017). Identification insert economic syariah on the subjects of economic senior high school. In Proceedings of the 2nd International Conference on Economic Education and Entrepreneurship (ICEEE 2017) (pp. 416-421).

Heykal, Mohamad. (2014). Analysis of level understanding financing mortgage sharia in sharia bank at Indonesia : Introduction study. Binus Business Review, 5(2), 519-526

Hidi, S. (2006). Interest: A unique motivational variable. Educational Research Review, 1(1), 69-82. https://doi.org/10.1016/j.edurev.2006.09.001

Indonesia, B. (2013). Islamic Banking Statistics. Jakarta: Direktorat Perbankan Syariah. 
Karaağaç, P. (2017). Teachers' views on activities practised in elementary schools. International Journal of Educational Research Review, 2(1), 34-40.

Mintaroem, K. (2009). Sharia economic curriculum at the faculty of economics, Airlangga university and its role in the Indonesian economy. Paper, Presented at the Forum of Deans of PTN in Indonesia, at the Faculty of Economics, University of Padjajaran, (pp. 2224).

Niswatin, N., \& Hasiru, R. (2017). Development of economic curriculum and Islamic accounting in schools (Study of Perception of Teachers and Students in Gorontalo City High School). Al-Ulum, 17(1), 86-99.

Palmer, D. H. (2009). Student interest generated during an inquiry skills lesson. Journal of Research In Science Teaching, 46(2), 147-165. https://doi.org/10.1002/tea.20263

Pintrich, P. R., \& Schunk, D. H. (1996). Motivation in education: Theory, research, and applications. (Englewood Cliffs, Ed.). NJ: Prentice-Hall.

Rahajeng, D. (2013). The role of Islamic banking system as the milestone towards indonesia micro economy development: A financial reports approach (September 12). Available at SSRN: https://ssrn.com/abstract=2354193 or http://dx.doi.org/10.2139/ssrn.2354193

Rudnyckyj, D. (2009). Spiritual economies: Islam and Neoliberalism in contemporary Indonesia. Cultural Anthropology, 24(1), 104-141. https://doi.org/10.1111/j.15481360.2009.00028.x

Sari, N. (2014). Redesain curriculum of sharia economy higher education Islamic religion: (An Effort to Give Birth to Professional Human Resources). Peuradeun, 2(3), 135-154.

Swarat, S., Ortony, A., \& Revelle, W. (2012). Activity matters: Understanding student interest in school science. Journal of Research In Science Teaching, 49(4), 515-537. https://doi.org/10.1002/tea.21010

Syafi'i, Imam. 2015. Islamic education in the thoughts of ibnu khaldun. Sekolah Tinggi Agama Islam (STAI) Yayasan Pendidikan Bhakti Wanita Islam (YPBWI) Surabaya.

Yusdani (2007). Islamization of the al-Faruqi model and its application in Islamic economics in Indonesia (An Epistemic Criticism). La_Riba Jurnal Ekonomi Islam, I(1), 77-94. 